\title{
CEO compensation and firm's cash holding: A pitch
}

\author{
Muhammad Atif ${ }^{\mathrm{a}, 1}$

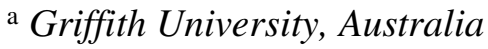

\begin{abstract}
This letter discusses the application of a pitch using Faff (2015a) pitching template, with intention to refine my idea and develop it in a systematic fashion. I find the pitching research template interesting; by applying it to my study that enhances the thought process and helps in precisely developing the idea before presenting it anywhere and starting work on the project. This PRL includes the brief commentary on personal reflection as few sections are quite daunting for junior researchers, but continual discussion is the key to refining the idea.
\end{abstract}

Keywords: Pitching research, Compensation, Corporate governance, Cash holding, Australia.

JEL codes: G32, G34

\section{Introduction}

I am applying the pitching research template originally developed by Faff (2015a and 2015b) to the research topic of compensation and cash holding. I recently enrolled in a $\mathrm{PhD}$ in finance at Griffith University, conducting research in the corporate governance area. I am new to research, and find it stressful to wander into a vast research field, looking at where to start. My supervisors suggest to involve in pitching research in order to refine and organise the idea on which I am currently working as part of my $\mathrm{PhD}$ thesis. I feel my research learning has greatly

${ }^{1}$ Corresponding author: Department of Accounting, Finance and Economics, Griffith Business School, Griffith University, 170 Kessels Road, Nathan 4111, Brisbane, Queensland, Australia. Tel: (+61) 073735 7295; email: muhammad.atif@griffithuni.edu.au 
expanded since I started to use pitch idea because it has resulted in a major shift in refining the idea. I spent some time reviewing the latest version of Faff (2015b) pitching research template; reading Beaumont (2015) pitch letter, and discussing these letters with other colleagues and staff to make the most of this new idea.

I applied the pitching research idea as a test case to my first paper. I find the "3-21" countdown idea quite an interesting way to organise my research. This countdown helps me to focus on relevant dimensions and the scope of study instead of wandering around in the literature. The "IDioTs" nomenclature used by Faff (2016) is more exciting to remember, and I use it to narrow down ideas, data, and the tools I plan to use in the research project. Another interesting visual depiction to use in the pitch letter for gaining self-understanding and clarification about contributions of the proposed project is the "Mickey Mouse" diagram. By using the template, I am now hopeful that I can discuss the first paper with my supervisors more precisely and seek their direct, prudent advice for improvement.

The remainder of this letter is organised as follows: Section 2 contains a brief discussion of my pitch application, while Section 3 contains personal reflections on the pitch letter, and section 4 is the conclusion.

\section{Brief discussion on pitch application}

It took over one week to prepare the first draft of this pitch letter and the completed template is shown in Table 1. I sought feedback from my supervisors to improve it further, and discussed it with colleagues to gain their comments. On average, I have spent an average of six hours a day in preparing the pitch letter. This time includes reading, writing, re-writing, meetings, and discussions with other academics to seek guidance. Certainly, the time I have spent in completing this letter was really fruitful in terms of learning and gaining a deeper insight into my project, CEO compensation and cash holding. This pitch letter is prepared in a nonlinear format as predicted by Faff (2016). First, I completed the sections that are clearer in my mind, and skipped over the others that require more time; I will return to them later. In a nutshell, I completed this template in a random fashion by focusing on different sections at different times. I found this template rather supportive with its cues, because a pitcher needs to focus on these signals to make the idea clearer and more understandable for themselves and the reader.

I have identified my key paper as Liu and Mauer (2011), which is my source of inspiration for working on this project. The main reasons for nominating this paper is its quality of ideas, discussion on the topic, and its forceful style of argument. Given the quality of Liu and Mauer (2011) study, a lot of work needs to be done in this area; I have explained this in answering the template questions "IDioTs" what's new, and so what. Then, the Motivation/Puzzle is also a considerable task to 
cope with and explain in only 300 words, but the cues help a lot to deal with this task and present it in a literary way.

\section{Personal reflection on pitch exercise}

As stated by Faff (2015b), the most difficult task for the novice researcher is to decide where to start. Subsequent reading of Beaumont (2015) and Ratiu (2015) also gives an impression of their pitch experience. As a new researcher, I never have any idea about how to identify contributions towards the literature because we are advised to "read and read". In doing so, novice researchers such as myself get lost in literature trying to identify gaps and contributions related to what I am going to do, and to what extent. This generic problem of an early-stage researcher is resolved by the "Mickey Mouse" diagram. This visual demonstration is a "light in the darkness" for understanding the contributions. This pitch letter gives me a vision of how to start research in a systematic and organised way, while thinking about ideas, tools, and contributions by drawing a "Mickey Mouse" diagram. I never thought about a potential journal for publication and the risk factors associated with my idea.

Pitching research broadened my understanding and knowledge about what may happen and where, at different stages of the project, as stated by section $\mathrm{K}$, Other Considerations. By using this template, I am able to select a project more rigorously by putting all the details in the template and thinking about what is missing and which area requires further attention. I find a few sections of the template quite daunting to deal with, such as stating the research question, selecting the key study and narrowing the motivation into a small number of words. Then, getting feedback and having discussions with other colleagues enabled me to deal with this task. Now, I have a clear understanding of my project and its contributions towards literature. Figure 1 shows my "Micky Mouse" diagram of the study.

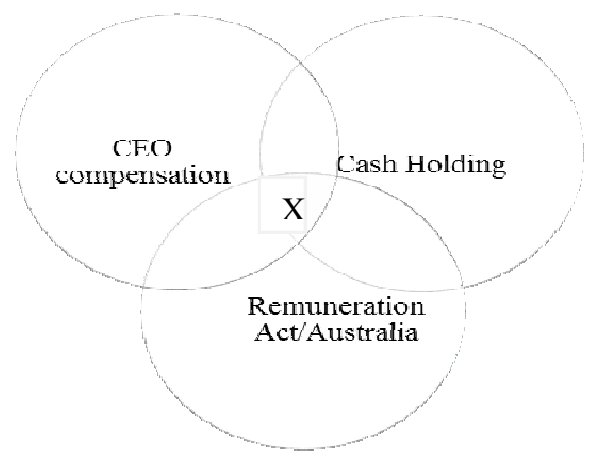

Figure 1. Mickey Mouse diagram characterizing novelty of research idea 
Table 1. Completed 2-page pitch template on CEO Compensation and Firm's Cash Holding

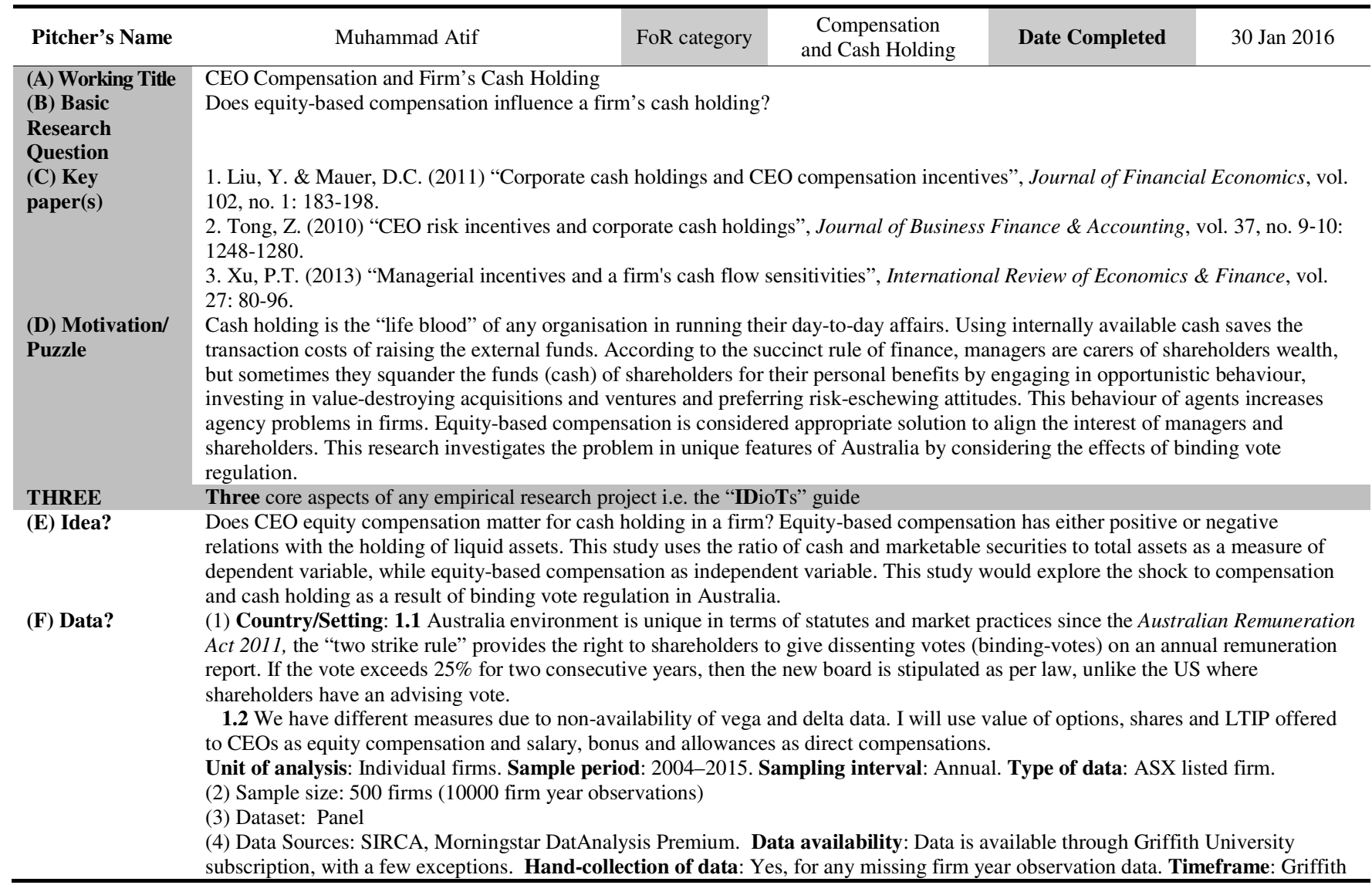




\begin{tabular}{|c|c|c|c|c|}
\hline Pitcher's Name & Muhammad Atif & & Date Completed & 30 Jan 2016 \\
\hline (G) Tools? & \multicolumn{4}{|c|}{$\begin{array}{l}\text { University subscribes to mentioned databases, so no major delays are expected. Research assistance: No major assistance required. } \\
\text { Funding/grants: N/A. Novel new data: No } \\
\text { (5) Missing data/observations: Yes, Missing year values are expected and will be collected from annual reports or company websites. } \\
\text { Database merging and Cleansing: Yes, the researcher may need to update the ASX codes in SIRCA while merging data from other } \\
\text { real time databases. } \\
\text { (6) Will your "test" variables exhibit adequate ("meaningful") variation to give good power? Yes. Quality/reliability of data: } \\
\text { Databases used for this study enjoy a good reputation in the financial press for their reliability and quality. } \\
\text { (7) External validity: No. Data and setting is unique in Australia because of non-binding statute and limitation on availability of risk- } \\
\text { based CEO incentives (vega and delta) in Australia. Value of shares and options given to CEO, s are available. Construct validity: } \\
\text { Since data is from reliable sources, it is expected to be accurate and produce nuanced results. } \\
\text { Empirical framework: (1) Baseline estimation through Panel fixed effect regression. (2) Difference in difference (DID) to explore } \\
\text { the effects of regulatory change and to address endogeneity concern. Econometric software: STATA licenced version purchased } \\
\text { from vendor. Knowledge of implementation of econometric: Assistance required to implement the advance statistical tests. } \\
\text { Compatibility of data with framework: Data is arranged as required for framework to estimate. Statistical validity: No. }\end{array}$} \\
\hline TWO & \multirow{2}{*}{\multicolumn{4}{|c|}{$\begin{array}{l}\text { Two key questions } \\
\text { (1) This study uses Australia because of the difference in settings and limitation on the US findings generalisability. (2) This research } \\
\text { explores the relationship between CEO equity pay and cash holding by analysing the effects of binding-votes in Australia after } 2011 . \\
\text { (3) Additional analysis through difference-in-difference technique to check exogenous shock of "two strike" rule before and after } 2011 \text {. } \\
\text { CEO equity compensation and cash holding provide an opportunity for outside stake-holders to assess the risk-taking and risk-averse } \\
\text { (opportunistic) attitude of managers. By having more, clear information, investors can decide to invest in firms or vice versa. } \\
\text { Governing boards and responsible committees for compensation can devise more acceptable pay structure for managers which is } \\
\text { acceptable for shareholders. }\end{array}$}} \\
\hline $\begin{array}{l}\text { (H) What's } \\
\text { New? }\end{array}$ & & & & \\
\hline ONE & \\
\hline $\begin{array}{l}\text { (J) } \\
\text { Contribution? }\end{array}$ & \multirow{2}{*}{\multicolumn{4}{|c|}{$\begin{array}{l}\text { This is the first study in the Australian setting to explore the effects of CEO compensation and cash holding using data after and } \\
\text { before the binding-vote regulation (unlike the prior US research). It also contributes additional analysis of exogenous shock through } \\
\text { "difference-in-difference" tool to have nuanced results and implications. } \\
\text { Collaboration: Not desired. Idea, Data, Tools: Feedback to improve and assistance required from internal econometrician. } \\
\text { Target Journal: 'A' ranked, Accounting and Finance (AFAANZ). Realistic/Sufficiently ambitious: This is a new idea and a novel } \\
\text { country, with a different setting and additional analysis, which makes the target journal an achievable goal. No result risk: Low. } \\
\text { Competitor risk: High: This is an unexplored area and there are more researchers in field who can grab the idea. Obsolescence risk: } \\
\text { Compensation is an extensively debated topic in top tier journals because it has been area of interest in the financial press with } \\
\text { different aspects since the GFC and the discussion is expected to continue with more pace in the future. Other risks: Data: Merging } \\
\text { data from different databases may pose a risk of inappropriateness. Scope: Appropriate coverage. }\end{array}$}} \\
\hline $\begin{array}{l}\text { (K) Other } \\
\text { Considerations }\end{array}$ & & & & \\
\hline
\end{tabular}




\section{Conclusion}

This pitch letter is an overview of my research project on CEO compensation and cash holding by using the Faff (2015a) template. I find research confronting as novice researcher, but the idea of pitching research works well for me, enabling me to overcome many initial obstacles, which are challenging in research. The first draft of the template was quite challenging to complete as I have never thought about some of the sections elaborated on above. I managed to get through the task by discussing the topic with other academics. After using this template, I can say it will be indispensable throughout my $\mathrm{PhD}$ study and after as well because of its systematic approach to refining and organising an idea and its different aspects. Unda (2015) narrates the whole experience as a "compass of research journey" to enhance the thought process and helps in confident and clear discussion of the research at forums.

\section{Acknowledgement}

This PRL is prepared for the first empirical chapter of author's doctoral thesis at Griffith University. Author is grateful to participants and academic panel of SIRCA Pitching research symposium 2016; especially Robert Faff, Zoltan Matolcsy, Gary Monroe, Karen Benson, Dave Michayluk, Eliza Wu, Herald Scheule and Kathleen Walsh for helpful comments and suggestions to execute the proposed research idea. Author is thankful to Securities industry research centre of Asia-Pacific (SIRCA) for travel grant. Author also acknowledges the feedback from Benjamin Liu, Allen Huang, Searat Ali and Robert Faff at early stage of this PRL. Author appreciates the reviewer's feedback in improving the quality of PRL.

\section{References}

Beaumont, S.J. (2015) "An investigation of the short-and long-run relations between executive cash bonus payments and firm financial performance: a pitch", Accounting \& Finance, vol. 55, no. 2: 337-343

Faff, R.W. (2015a) "A simple template for pitching research", Accounting \& Finance, vol. 55, no. 2: 311-336

Faff, R.W. (2015b) "Pitching Research", Available at SSRN: http://ssrn.com/abstract=2462059 
Faff, R.W. (2016) "Mapping pitching research tasks into the rsd7 framework: A pedagogic perspective", Available at SSRN: http://ssrn.com/ abstract $=2724451$.

Liu, Y. \& Mauer, D.C. (2011) "Corporate cash holdings and CEO compensation incentives", Journal of Financial Economics, vol. 102, no. 1: 183-198

Ratiu, R.V. (2015) "Financial reporting of European banks during the GFC: a pitch", Accounting \& Finance, vol. 55, no. 2: 345-352

Unda, L.A. (2015) "Board of director's characteristics and credit union financial performance: a pitch", Accounting \& Finance, vol. 55, no. 2: 353-360 